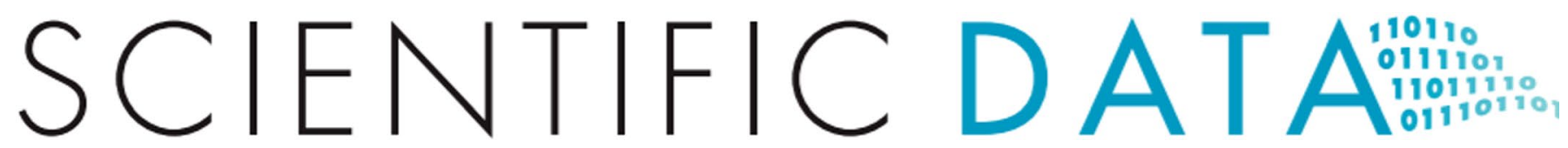

Check for updates

OPEN

Published online: 23 February 2021

\title{
Author Correction: Arabidopsis proteome and the mass spectral assay library
}

Huoming Zhang ${ }^{D}$, Pei Liu, Tiannan Guo ${ }^{D}$, Huayan Zhao, Dalila Bensaddek, Ruedi Aebersold (iD) \& Liming Xiong

Correction to: Scientific Data https://doi.org/10.1038/s41597-019-0294-0, published online 22 November 2019

The spelling of King Abdullah University of Science and Technology has been corrected for author affiliations 1 and 2. This error has been corrected in both the HTML and PDF versions of this Data Descriptor.

(c) (i) Open Access This article is licensed under a Creative Commons Attribution 4.0 International License, which permits use, sharing, adaptation, distribution and reproduction in any medium or format, as long as you give appropriate credit to the original author(s) and the source, provide a link to the Creative Commons license, and indicate if changes were made. The images or other third party material in this article are included in the article's Creative Commons license, unless indicated otherwise in a credit line to the material. If material is not included in the article's Creative Commons license and your intended use is not permitted by statutory regulation or exceeds the permitted use, you will need to obtain permission directly from the copyright holder. To view a copy of this license, visit http://creativecommons.org/licenses/by/4.0/.

(C) The Author(s) 2021 